\title{
RELATION OF THE ICT WITH NEUROEDUCATION, INCLUSION, PLURICULTURALITY AND ENVIRONMENTAL EDUCATION THROUGH A CONFIRMATORY FACTORIAL ANALYSIS STUDY
}

RELAÇÃO DAS TIC COM A NEURO-EDUCAÇÃO, INCLUSÃO, PLURICULTURALIDADE E EDUCAÇÃO AMBIENTAL ATRAVÉS DE UM ESTUDO DE ANÁLISE FATORIAL CONFIRMATÓRIA

\author{
Antonio Hernández Fernández \\ Universidad de Jaén, Espanha \\ antonio.hernandez@ujaen.es
}

\begin{abstract}
The present work aims to analyze the relationship of ICT with neuroeducation, educational inclusion, environmental education and pluriculturality through Confirmatory Factor Analysis (Structural Equation Model - SEM) of a created ad hoc and a validated and confirmed scale. For the search for answers, a non-experimental, descriptive, explanatory and correlational research process was carried out. The instrument used to collect the data was a Likert scale, which has been validated in content and with a good Cronbach's alpha (.825). The construct validity was carried out with an exploratory factorial analysis (KMO (.764), Bartlett (Sign.000), Determinant (2.891E-30)). The sample was of 292 students of Master's Degree in Teacher Training from the University of Jaen (Spain). The Confirmatory Factorial Analysis (SEM) allowed us to conclude that this relationship is possible, with greater strength between education technologies and educational inclusion, and between the former and pluriculturality, and with less strength between environmental education and neuroeducation, what should be taken into account to implement in university training programs.
\end{abstract}

KEYWORDS: ICT. Neuroeducation. Educational inclusion. Environmental education. Pluriculturality.

RESUMO: O presente trabalho tem como objetivo analisar a relação das TIC com a neuroeducação, inclusão educacional, educação ambiental e pluriculturalidade através da Análise Fatorial Confirmatória (Structural Equation Model - SEM) de uma escala, criada ad hoc, validada e confirmada. Para a busca de respostas, foi realizado um processo de pesquisa não-experimental, descritivo, explicativo e correlacional. O instrumento utilizado para a coleta dos dados foi uma escala Likert, que foi validada em conteúdo e com um bom alfa do Cronbach (.825). A validade da construção foi realizada com uma análise fatorial exploratória (KMO (.764), Bartlett (Sign.000), Determinante (2.891E-30)). A amostra foi de 292 alunos de pós-graduação da Universidade de Jaén (Espanha). A análise fatorial confirmatória (modelo de equação estrutural) nos permitiu concluir que essa relação é possível, com maior força entre as tecnologias educacionais e a inclusão educacional, e entre a primeira e a pluriculturalidade, e com menor força entre educação ambiental e neuroeducação, o que deve ser levado em conta para implementar em programas de treinamento universitário.

PALAVRAS-CHAVE: TIC. Neuroeducação. Inclusão educacional. Educação ambiental. Pluriculturalidade. 


\section{Introduction}

At the university level, students who study "education" have curricular subjects of different types and content. Thus, in the Spanish curricula, undergraduate students study ICT, inclusive education and environmental education; however, until now, in the year 2020, we do not find subjects that deal specifically with neuroeducation and pluriculturality. In the students who are studying the official master's degree in teacher training, whose objective is to be teachers in secondary education, we do not find subjects specifically dealing with ICT, neuroeducation, educational inclusion, environmental education or pluriculturality. This student, on the other hand, has a very diverse origin (architecture, engineering, medicine...), so we can safely say that in their respective undergraduate studies they have not fully studied the areas that are the subject of study here. It is for this reason that we take this group as a study population, as we will try to establish whether there is a relationship between these areas, and see the implications that this relationship has for incorporating them into university studies.

In postgraduate training, a master's degree has appeared in recent years aimed at establishing the professionalization of secondary and language teachers: the University Master's Degree in Compulsory Secondary Education, Baccalaureate, Vocational Training and Language Teaching which has replaced the old Pedagogical Adaptation Course (PAC, 1-10-09), which is compulsory for anyone who wants to enter this profession. The design of the course is established by the Ministry of Education, although it is subject to modification depending on the Autonomous Community and the University (BUENDÍA et al., 2011). The new legislations, as well as the emerging social demands, require different types of approaches for the learning of secondary school teachers, guided by rigour, cultural, psycho-pedagogical and didactic training. The most important aim of this master's degree is for student to acquire the necessary skills to exercise the teaching profession. Some of the fundamental challenges in the training of secondary teachers are: training in new functions, pedagogical reformulation of training, the relationship between theory and practice, the low level of teacher professionalization, training in ICTs, lax rules of access to training, and the procedure for incorporation into the teaching profession (TERIGI, 2009, cited in GUTIÉRREZ et al., 2019). Linked to these new requirements is school failure, understood here as not graduating from secondary education, which is a serious problem that must be taken into consideration in order to improve national education systems. This phenomenon is considered to be learning difficulties that can lead to student failure (ESCUDERO, 2012). The factors related to school dropout are diverse, mostly related to social, economic, educational, family and personal contexts (HERNÁNDEZ et al., 2018). Some knowledge has become very relevant for the training of future education professionals, especially in the stages of primary and secondary education. That is why we propose this research, because we not only think it is important to study and train in neuroeducation or pluriculturality, but also to analyze whether ICT contribute to inclusion or pluriculturality, or whether neuroeducation has an influence on ICT etc. Before presenting the research to be carried out, we are going to provide some references on each research topic, in order to have a common and current idea of each one of them.

In Spain, one of the most important points of the School 2.0 plan is that which refers to the training of teachers in ICT (SUÁREZ et al., 2013). Information and communication technologies have burst into teaching practices, becoming a mediating agent in the teaching and learning processes (ERTMER; OTTENBREIF; LEFTWICH, 2010), in 
addition, we find numerous studies on the need for changes in the traditional concept taught in schools, so Gil and Fernandez (2020) tell us about the importance of Instagram, the value of ICT in different disabilities, such as autism (ALMEIDA et al., 2020), the Projeto Novos Rumos 4.0 (SGORLA; COSTA; ZAVILENSKY, 2020).

In relation to inclusion, the world's education systems face the challenge of providing quality education to children and young people. In the face of these demands there is undoubtedly interest in the idea of inclusive education, however, this term still remains confusing (ECHEITA; AINSCOW, 2011). Educational inclusion is a form of response and attention to the diversity of the syllabuses in the educational context, with a broad projection of equal educational opportunities and all within an environment that promotes the integral, personal and academic development of all students (LEHOHLA; HLALELE, 2012). Analyzing other studies, González, Martín Pastor and Orgaz (2017) appear who carried out a questionnaire oriented to the evaluation of the initial formation in inclusive education of university students of the education degrees. The environmental education would enter to form part of these knowledges, let us call them "essential" for the education of the 21st century. Environmental education appears as a proposal for social action that seeks to mitigate natural disasters and to educate individuals so that they can understand the environment in which they live and understand their capacity to act in the face of natural disasters. (ORDONEZ-DIAZ; MONTES-ARIAS; GARZON-CORTES, 2018) Some previous studies can be found in the scientific literature that have already assessed the effectiveness of scales on environmental education, such as the Scale for the Assessment of Pro-environmental Attitudes (EAPA) of university students (CASTAÑEDO, 1995).

Related to all of the above, we undoubtedly have the cultural diversity (pluriculturality), which as a consequence of migratory movements produced in the last decades, the population masses have experienced deep social changes, both in Europe and more specifically in the case of Spain. Pluricultural diversity has become a considerable factor within social policies, as well as research that places it as an object of study in higher education, where we did not have current jobs (ALGARRA, 2020). However, despite the fact that this diversity appears under different focuses (gender differences, social and ethnic classes etc.), it has been the arrival of foreign emigration that has led to the adoption of legislative measures and pedagogical modifications in order to adapt to this new social panorama. Peñalva and Soriano (2010), show how the presence of interculturality as an obligatory content is very insignificant within initial training, in this case of future educators and teachers. This inevitably leads us to think that in the other grades, especially those not related to the humanistic and social, the contributions to culturality will be nil.

Another concept that has emerged in recent years in all countries is that of neuroeducation, within the most recent teaching methods currently appears immersed in this new science, which is understood as a new line of thought and action whose primary objective is to bring educators closer to knowledge related to the brain and learning, in an attempt to unite Pedagogy, Cognitive Psychology and Neurosciences (CAMPOS, 2010), in addition to establishing the basis for an optimal teaching and learning process (LUQUE; LUCAS, 2020).

In relation to all this, and referring to the population of study, one of the most relevant characteristics of the master's degree in teacher training, and that we pointed out before, is the diversity of academic itineraries with which the population of study accesses 
and that finally guides them to exercise as teachers of Secondary Education. Different studies alert us to the lack of complete pedagogical training in the University Master's Degree in Compulsory Secondary Education, Baccalaureate, Vocational Training and Language Teaching, making it necessary to develop more competencies related to pedagogical, communication, empathy and cooperative work skills, etc. (MANSO AYUSO; MARTÍN, 2014). In this way, as it can be appreciated along all the exposed, there are investigations for each one of the dimensions studied in this investigation, nevertheless, there are not found in the literature studies that in a conjunctive way include the dimensions that are proposed here, for the students of Master's Degree in Teacher Training.

\section{Method}

This research is based on the following general objective: to analyze the relationship between ICT, neuroeducation, educational inclusion, environmental education and pluriculturality, in higher education. The research design is non-experimental, descriptive, explanatory and correlational, quantitative methodology and we take as reference an interpretative paradigm. In order to carry out the research, a Likert scale is used as a research instrument.

The population that can be investigated is made up of the students of the Master's Degree in Teacher Training at an Andalusian university. This population is made up of 300 subjects. We will take the whole population, so the sample coincides with the population. The Likert scale, after several absences and dropouts, was finally answered by 292 subjects.

The dimensions of this study, extracted from the theoretical framework and the construction of the Likert scale are A.-Environmental education, B.-Educational technologies, C.-Pluriculturality, D.-Educational inclusion and E.-Neuroeducation. Consequently, we establish as independent variables: environmental education, educational technologies, pluriculturality, educational inclusion and neuroeducation. The dependent variables are: knowledge, perception. As an instrument we opted for a Likert scale, which was constructed with an operationalization table. Five dimensions are established, with a total of sixty-two items. The content validation was done with an expert judgment and pilot test, secondly, a factorial analysis was done to validate the scale in its construction using SPSS v25 software. The reliability analysis was performed by calculating Cronbach's alpha, giving a score of .825, which is considered good (GEORGE; MALLERY, 2003). Lisrel 8.80 was used for the structural modeling.

\section{Results}

The validity of the content was carried out by fifteen specialist doctors (MALLA; ZABALA, 1978) authorised to carry out this evaluation and belonging to different universities. Their competence coefficient was calculated as $k=0.9$, which shows a high level of competence (GARCÍA; FERNÁNDEZ (2008), LÓPEZ (2008); MENGUAL (2011)). After analyzing the validation questionnaires, some questions were readjusted, without 
affecting the substance of the question. On the other hand, a pilot test was carried out on a subgroup of the sample to review comprehension difficulties, identify questions that generated doubt, etc., using the corresponding checklist (IRAOSSI, 2006). The results of the pilot test were satisfactory and the instrument was considered validated in its content.

The validity of the construct was carried out through exploratory factor analysis. The factorial analysis technique we have applied follows the guidelines set out in the following stages (GARCÍA FERRANDO, 2015; DÍAZ DE RADA, 2002):

1.-Study of the correlation matrix: it is necessary to study the correlation matrix to check if our data are suitable to carry out a Factorial Analysis. To do this, this matrix must have a certain structure. To check this, we have used the Kaiser-Meyer-Olkin measure of sampling adequacy (KMO coefficient), in our case the value is 0.764 , following Kaiser (1974) the value is acceptable, the result of Bartlett's sphericity test is .000 and the determinant $2.891 \mathrm{E}^{-30}$, so we continue with the analysis.

2.-Extraction of the factors: once it was decided that the factorial analysis can give good results, the extraction of the factors is carried out. In a good extraction these values should be high (the closer to one the better) in all variables. The resulting of communalities showed us that the factors have a value greater than 0.606 so it is not necessary to eliminate any item from the factor analysis. The best represented items are: B17 (.845) The use of ICT in school settings facilitates coordination, communication and cooperation among teachers. C30 (,852) - It is relevant to introduce cultural studies in the current school in order to achieve a more just and equal future society. D35 (.847) The concepts of integration and inclusion in schools are of the same nature. D38 $(, 859)$ Pupils should receive assistance according to their needs outside the ordinary classroom. D48 $(, 867)$ It seems more appropriate to speak of disability rather than functional diversity, as this term is more explicit. E51 (849) Knowledge of neurosciences allows us to better understand the situation of persons with functional diversity. The worst represented items are: A01 (,626).Environmental education is a training process that allows awareness of the importance of the environment. C22 (,682) - The term multicultural refers to the current of thought that studies the presence of heterogeneous cultures in the same space and time. D39 $(, 693)$ Equity among people is the underlying value of inclusion.

3-Rotation of the factors: To carry out the rotations there are several methods according to the criterion of optimality. One of them is the Varimax Rotation that optimizes the factorial loads so that the most extreme loads are obtained in the factors (high and low). There are rules to know the most adequate number of factors to conserve, for example, the one known as Kaiser's criterion (1974) that indicates that it is necessary to conserve the main components whose own values are greater than the unit, although the most used criterion is that of observing the percentage of total variance explained by each component or factor, and when this reaches an accumulated percentage considered high, in our case they are the first 18 factors, which explain 77,789 of the accumulated variance (Table 1). 
Table 1: Total variance explained.

\begin{tabular}{|c|c|c|c|c|c|c|}
\hline \multirow[t]{2}{*}{ Component } & \multicolumn{3}{|c|}{ Initial Eigenvalues } & \multirow{2}{*}{$\begin{array}{l}\text { Extraction Sums of } \\
\text { Squared Loadings } \\
\text { Total }\end{array}$} & \multirow[b]{2}{*}{$\%$ of Variance } & \multirow[b]{2}{*}{ Cumulative \% } \\
\hline & Total & $\%$ of Variance & Cumulative \% & & & \\
\hline 1 & 12,701 & 20,486 & 20,486 & 12,701 & 20,486 & 20,486 \\
\hline 2 & 5,107 & 8,237 & 28,723 & 5,107 & 8,237 & 28,723 \\
\hline 3 & 4,616 & 7,445 & 36,168 & 4,616 & 7,445 & 36,168 \\
\hline 4 & 2,903 & 4,683 & 40,851 & 2,903 & 4,683 & 40,851 \\
\hline 5 & 2,713 & 4,376 & 45,227 & 2,713 & 4,376 & 45,227 \\
\hline 6 & 2,518 & 4,062 & 49,289 & 2,518 & 4,062 & 49,289 \\
\hline 7 & 2,326 & 3,751 & 53,040 & 2,326 & 3,751 & 53,040 \\
\hline 8 & 2,030 & 3,275 & 56,315 & 2,030 & 3,275 & 56,315 \\
\hline 9 & 1,875 & 3,024 & 59,339 & 1,875 & 3,024 & 59,339 \\
\hline 10 & 1,570 & 2,533 & 61,872 & 1,570 & 2,533 & 61,872 \\
\hline 11 & 1,504 & 2,426 & 64,298 & 1,504 & 2,426 & 64,298 \\
\hline 12 & 1,424 & 2,297 & 66,596 & 1,424 & 2,297 & 66,596 \\
\hline 13 & 1,382 & 2,229 & 68,825 & 1,382 & 2,229 & 68,825 \\
\hline 14 & 1,227 & 1,979 & 70,804 & 1,227 & 1,979 & 70,804 \\
\hline 15 & 1,173 & 1,891 & 72,695 & 1,173 & 1,891 & 72,695 \\
\hline 16 & 1,113 & 1,796 & 74,491 & 1,113 & 1,796 & 74,491 \\
\hline 17 & 1,034 & 1,667 & 76,158 & 1,034 & 1,667 & 76,158 \\
\hline 18 & 1,011 & 1,631 & 77,789 & 1,011 & 1,631 & 77,789 \\
\hline 19 & 0,963 & 1,554 & 79,343 & & & \\
\hline
\end{tabular}

Extraction

Method:

Principal

Component

Analysis.

Source: own elaboration.

4 - Study of factorial scores: Table 2 shows the analysis of variance explained and accumulated, as well as the determination of factors and distribution of items according to the highest level of saturation by factors (we have discarded the factors that have less than three items, leaving only two factors that may have an acceptable reliability).

Table 2: Analysis of variance explained and accumulated.

\begin{tabular}{|llll|}
\hline Factor & Title & $\begin{array}{l}\text { \% of } \\
\text { cumulative } \\
\text { variance }\end{array}$ & Items integrated in each factor of the questionnaire. \\
\hline I & $\begin{array}{l}\text { A (Environmental } \\
\text { Education) }\end{array}$ & $20,486 \%$ & $\begin{array}{l}\text { A01.-Environmental education is a process of formation that } \\
\text { allows the awareness of the importance of the environment. } \\
\text { A02.-Environmental education tries to achieve that individuals } \\
\text { understand the environment and acquire the knowledge, } \\
\text { values and practical skills to participate in the prevention and } \\
\text { management of the quality of the environment. } \\
\end{array}$ \\
& & A03.-Environmental education promotes the development of \\
& & \\
& & \\
& &
\end{tabular}


B (Educational technologies)

C (Pluriculturality)

D (Educational Inclusion)

(Neuroeducation)
A04.-Environmental education should be considered, in importance, as language or mathematics.

A05.-Environmental education should address the issue of environmental crisis.

A06.-Environmental education should address the issue of sustainable development.

A07.-Environmental education is a tool to transform reality.

A08.-Environmental education encourages active participation in society and promotes shared responsibility.

A10.-Environmental education tries to improve the connection between educational action and productive and management tasks.

B15.-The use of New Technologies facilitates access to new sources of information, surpassing in this aspect traditional methodologies.

B16.-The adequate implementation of New Information and Communication Technologies in the school facilitates communication between family and school.

C22.-The term multicultural refers to the current of thought that deals with the study of the presence in the same space and time of heterogeneous cultures.

C23.-Interculturality is the interaction between two or more cultures equally, favoring the inclusion and a harmonic coexistence of all individuals from a respectful relationship between cultures.

C25.-Transculturality is the way in which cultures, by interaction, generate new joint cultural facts.

C30.-It is relevant to introduce cultural studies in the current school in order to achieve a more just and egalitarian future society.

C31.-It is possible to establish a correlation between the concepts of interculturality and inclusion.

C32.-Education in interculturality could have a positive impact on the educational inclusion of students with functional diversity.

D36.-Teachers must be able to adapt their teaching practices to the needs of their students.

D37.-Inclusive education consists of making educational practices accessible to all people.

D39.-Equity between people is the underlying value of inclusion.

D42.-Educational inclusion is the process of analysis by which we try to eliminate the barriers of distinction between students and teachers.

D45.-Accessibility is related to school inclusion.

D46.-Accessibility is focused on the elimination of architectural obstacles for people with reduced mobility and people with sensory limitations.

D47.-Accessibility means promoting free access to environments, but also to goods and services for people with disabilities in the same conditions as the rest of the population.

D49.-It seems more ethical to use the term functional diversity when talking about people with disabilities. 


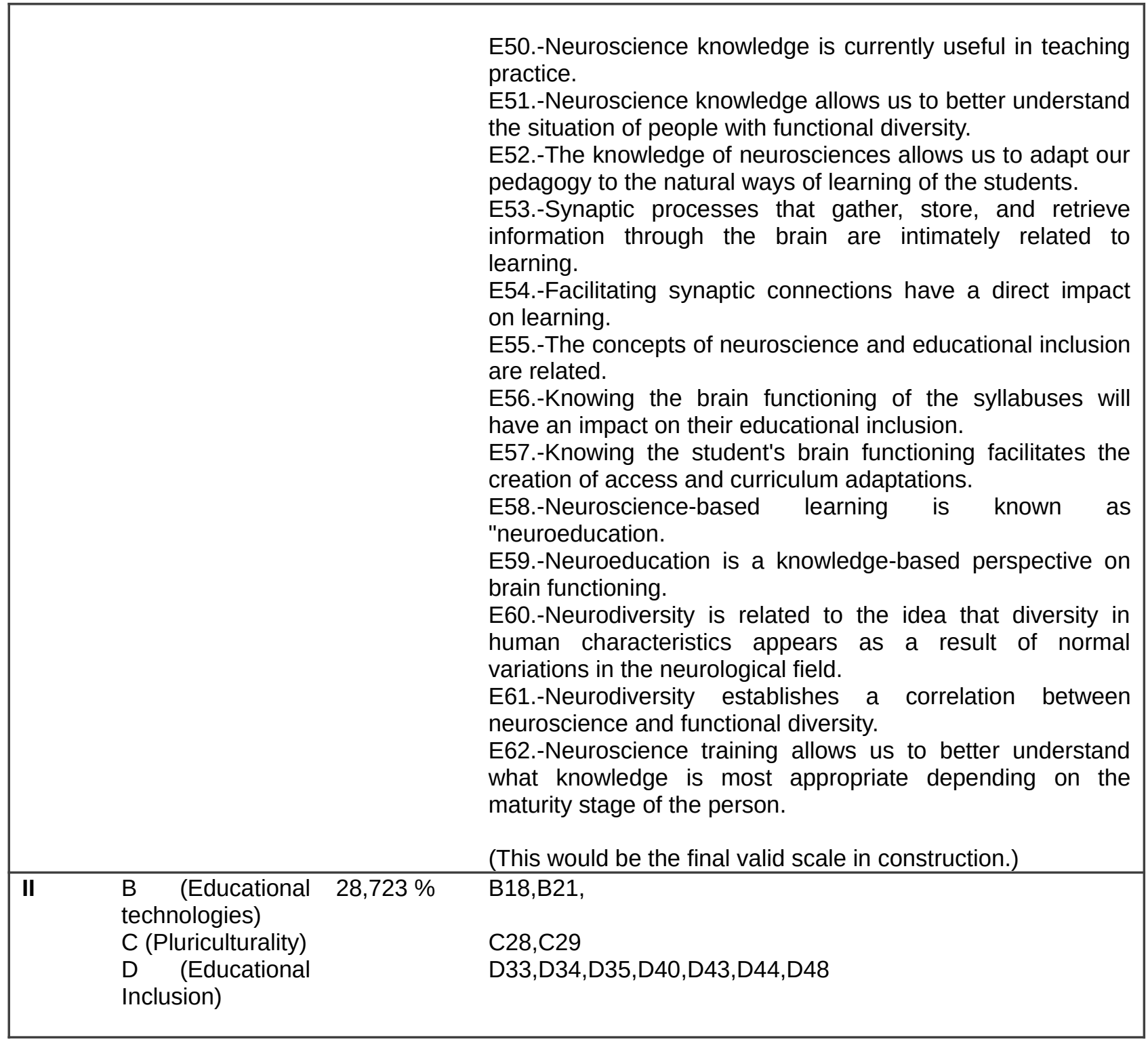

Source: own elaboration.

We have calculated Cronbach's alpha of both factors: Factor 1: ,935 (38 items), "excellent" rating. Factor 2: ,779 (11 items), rating "acceptable". We took the factor 1, which presents a higher reliability than the original scale itself, getting a final scale of 38 items, reducing 24 items.

\subsection{Correlation analysis}

To carry out the correlation, we subjected the Likert scale to the KolmogorovSmirnov test, which explains that the data do not follow a normal distribution, so the Spearman correlation has to be used. Next in Table 3 we show the correlations between items that have significant value (0.05): 
Table 3: Significant correlations.

\begin{tabular}{|l|l|l|l|l|}
\hline A1>A2 (.658) & B11>B15 (.552) & C22>A6 (.516) & D33>D35 (.640) & E50>E51 (.715) \\
A2>A1 (.658) & B12>B17 (.461) & C23>C32 (.523) & D34>D35 (.501) & E51>E52 (.720) \\
A3>A5 (.577) & B13>D40 (.509) & C24>C26 (.387) & D35>D33 (.640) & E52>E51 (.720) \\
A4>A5 (.454) & B14>A9 (.343) & C25>C26 (.507) & D36>D47 (.500) & E53>E60 (.602) \\
A5>A6 (.766) & B15>B11 (.552) & C26>C27 (.546) & D37>D49 (.506) & E54>562 (.540) \\
A6>A5 (.766) & B16>B17 (.533) & C27>C26 (.546) & D38>E56 (.289) & E55>E62 (.634) \\
A7>A5 (.509) & B17>B16 (.533) & C28>E60 (.409) & D39>D42 (.503) & E56>E57 (.596) \\
A8>A9 (.535) & B18>B19 (.476) & C29>E58 (.439) & D40>B13 (.509) & E57>E56 (.596) \\
A9>A8 (.535) & B19>B18 (.476) & C30>C23 (.482) & D41>D48 (.476) & E58>E59 (.553) \\
A10>A9 (.489) & B20>B17 (.479) & C31>C32 (.572) & D42>C22 (.548) & E59 $>$ E62 (.632) \\
& B21>B19 (.358) & C32>C31 (.572) & D43>D48 (462) & E60 $>$ E61 (.546) \\
& & & D44>C29 (.410) & E61>E62 (.583) \\
& & & D45>D42 (.450) & E62>E58 (.706) \\
& & & D46>D47 (.545) & \\
& & & D47>A1 (.564) & \\
& & & D48>D41 (.476) & \\
& & & & \\
& & & &
\end{tabular}

Source: own elaboration.

The highest values, from highest to lowest, correspond to items $A 5<>A 6$, E51<>E52, E50>E51 and finally E62>E58. In other words, people who think that environmental education should deal with the subject of environmental crisis also think that it should deal with sustainable development. Similarly, the subjects interviewed agree that knowledge about neurosciences allows us to better understand the situation of people with functional diversity, as well as to adapt our pedagogy to the natural ways of learning of the students. Also, the people who say that currently the knowledge about neurosciences is useful in the teaching practice, correlates significantly that allow us to better understand the situation of people with functional diversity. Finally, the subjects who agree that training in neurosciences allows us to better understand what knowledge is the most appropriate depending on the maturity stage in which the person is, state that learning based on neurosciences is known as "neuroeducation".

\subsection{Confirmatory Factorial Analysis}

The SEM methodology, which we will carry out with the Lisrel 8.80 software, consists of a series of phases according to Kaplan (2000) and Kline (2005) that we will specify in four.

\section{Phase I.-Specification of the Measurement Model}

At this stage, the latent features and the dimensions that represent them are established as variables of interest in a substantive theory. This stage is of a conceptual nature and it formulates the structure of relationships between the latent variables represented by the dimensions of the instrument and the responses to the context questionnaire. The Conceptual Model of the Likert scale obtained from the exploratory factor analysis is composed of 38 observed variables that are grouped into five dimensions. For the structural study we will use the factorial scale with 38 observed variables. 
Phase II - Identification. Computational Implementation of the System of Structural Equations.

To determine if the model is identified we must calculate the degrees of freedom ( $\mathrm{gl}$ ), in our case the value is 518 , so we can say that the model is over-identified.

\section{Phase III - Parameter estimation}

The model estimation phase (Figure 1) includes a graphic representation of the theoretical-conceptual structure of the instrument under analysis. This representation is the basis for the formulation of the reproduced matrix that will be compared with the derived matrix. For the Likert scale the graphic representation is shown in the figure, in which the ovals represent the five latent variables (constructs) and the boxes the 38 variables observed, which together make up the dimensionality of the instrument. 
Figure 1: Graphical representation of the natural measurement model of the Likert scale.

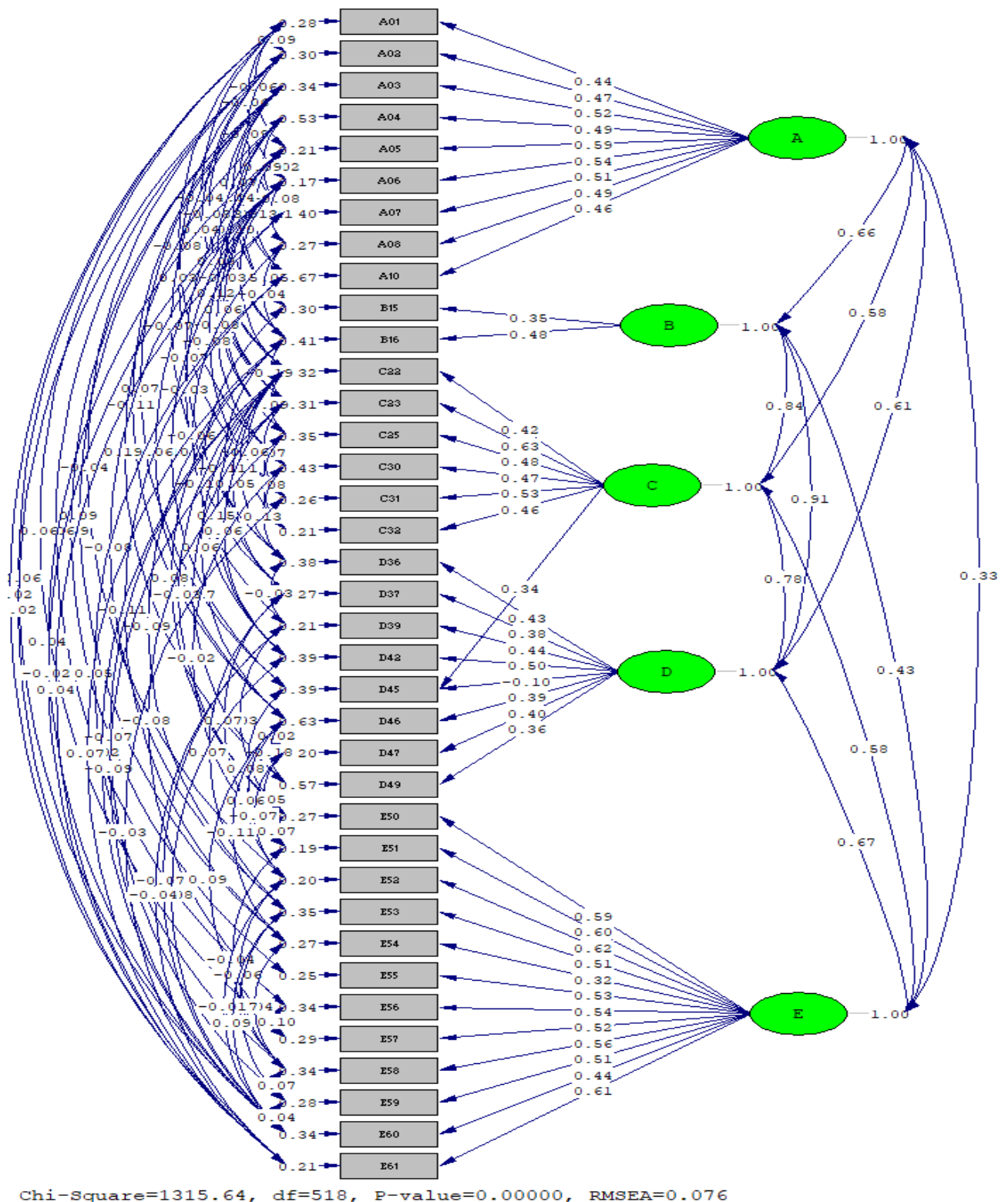

Source: own elaboration.

We reviewed the regression coefficients between the latent and observed variables, the interpretation being as follows.

Dimension A (Environmental education): -More influence of the latent variable on: A05.-In environmental education the subject of environmental crisis should be dealt with. Less influence of the latent variable on: A01.-Environmental education is a training process that allows awareness of the importance of the environment.

Dimension B (Educational technologies):-More influence of the latent variable on: B16.-Adequate implementation of New Information and Communication Technologies in the school facilitates communication between family and school -Lesser influence of the 
latent variable on: B15.-The use of New Technologies facilitates access to new sources of information, surpassing in this aspect traditional methodologies.

Dimension C (Pluriculturality): -More influence of the latent variable on: C23.Interculturality is the interaction between two or more cultures equally, favoring the inclusion and harmonious coexistence of all individuals from a respectful relationship between cultures. -Lesser influence of the latent variable on: C22.-The term multicultural refers to the current of thought that studies the presence of heterogeneous cultures in the same space and time.

Dimension D (Educational inclusion): -More influence of the latent variable on: D42.Educational inclusion is the process of analysis by which an attempt is made to eliminate barriers of various kinds that limit the presence, learning and participation of students in school life, especially the most vulnerable. -Lesser influence of the latent variable on: D45.-Accessibility is related to school inclusion.

Dimension E (Neuroeducation): -More influence of the latent variable on: E52.-The knowledge of neurosciences allows us to adapt our pedagogy to the natural ways of learning of the students. -Lesser influence of the latent variable on: E52: E54.-Facilitate synaptic connections have a direct impact on learning.

Inter-dimensional relations: A-B (.66), A-C (.58), A-D (.61), A-E (.33), B-C (.84), B-D (.91), B-E (.43), C-D (.78), C-E (.58), D-E (.67)

The strongest relationship between the latent variables is given by:

$\mathrm{B}$ (Educational technologies)-D (Educational inclusion) (.91)

B (Educational technologies)-C (Pluriculturality) (.84)

The lowest ratio is given by:

A (Environmental education)-E (Neuroeducation) (.33)

Phase IV - Evaluation of the adjustment Application of indexes and criteria of goodness of fit.

At this stage we use indices (Table 4) and goodness-of-fit criteria to relate the validated evidence to the dimensional structure of the instrument being evaluated:

Table 4: Goodness-of-fit indices.

\begin{tabular}{|l|l|}
\hline \multicolumn{1}{|c|}{ Test de $\mathrm{X}^{2} \mathrm{y} \mathrm{X}^{2} / \mathrm{gl}$} & \\
\hline $\mathrm{X} 2$ & 1315.64 \\
\hline Degrees of freedom & 518 \\
\hline p-value & 0.000 \\
\hline $\mathrm{X} 2 / \mathrm{gl} \quad$ & 2.53 \\
\hline \multicolumn{1}{|c|}{ Absolute adjustment rates } & \\
\hline GFI (Goodness of Fit Index) & .77 \\
\hline RMSEA (Root Mean Square Error of Aproximation) & .076 \\
\hline NCP (Non-Centralized Parameter) & $797.64(694.50-908.44)$ \\
\hline SRMR (Standardized Mean Quadratic Residue) & .043 \\
\hline RMS (Root Mean Square Residuals) & .075 \\
\hline ECVI (Expected Cross Validation Index) & $6.36(5.97-6.78)$ \\
\hline
\end{tabular}


Belo Horizonte, v. 13, n. 3, p. 262-277, set.-dez. 2020 - ISSN 1983-3652 DOI : $10.35699 / 1983-3652.2020 .25739$

\begin{tabular}{|l|l|}
\hline \multicolumn{1}{|c|}{ Incremental adjustment rates } & \\
\hline AGFI (Adjusted Goodness of Fit Index) & .69 \\
\hline IFI (Incremental Fit Index). & .95 \\
\hline NFI (Normed Fit Index). & .92 \\
\hline $\begin{array}{l}\text { TLI or NNFI (Tucker-Lewis Index or Non-Normed Fit } \\
\text { Index) }\end{array}$ & .94 \\
\hline RFI (Relative Fit Index) & .90 \\
\hline CFI (Comparative Fit Index) & .95 \\
\hline \multicolumn{1}{|c|}{ Parsimony rates } & \\
\hline PNFI (Parsimonius Normed Fit Index). & .72 \\
\hline PGFI (Parsimonius Goodned of Fit Index) & .57 \\
\hline AGFI (Adjusted Goodness of Fit Index) & .69 \\
\hline
\end{tabular}

Source: own elaboration.

In summary: $X^{2} / g I$ (2.53). IAA: GFI (.77), RMSEA (.076), NCP (797.64), SRMR (.043), RMS (.075), ECVI (6.36). IAI: AGFI (.69), IFI (.95), NFI (.92), TLI/NNFI (.94), RFI (.90), CFI (.95). IP: PNFI (72.), PGFI (.57), AFGI (.69). As can be seen, the criteria for all goodness-of-fit indices are met, so the model is fully confirmed.

\section{Discussion and conclusions}

The present research has as general objective to analyze the relationship of ICT with neuroeducation, educational inclusion, environmental education and pluriculturality through the Confirmatory Factorial Analysis (SEM) of a scale, created ad hoc. The scale presents a very good content validity, an excellent reliability, and through the exploratory factorial analysis a construct validity that allows us to have a really excellent instrument, besides, the confirmatory analysis validates the model of interrelations between the investigated topics. The main limitation of this study is determined by the selected sample, only students of a master's degree from a Spanish university. In the near future we want to extend this sample and eliminate this limitation. From the exploratory factorial analysis, we can contribute some interesting conclusions, among them that, although we have new terms, it seems more appropriate to continue talking about disability, as well as the importance of including cultural or neuroscience studies in teacher training. It is not relevant, although it is worrying, the little importance given to environmental education, or to equity in inclusion. From the correlation analysis, some hopeful conclusions arise, so that environmental education is correlated with sustainable development, which neuroscience gives a scientific basis to the teacher's performance. Finally, the most remarkable conclusions that give sense to this research are provided by the Confirmatory Factorial Analysis (SEM), showing that in environmental education the most important concept is the environmental crisis, in educational technologies it is the one that facilitates the relationship between family and school, in pluriculturality that the interaction of cultures favors inclusion, eliminating barriers of all kinds, and finally that knowledge in neurosciences is applicable in the classroom, so we conclude by saying that the strongest relationship is given by "technologies" with "educational inclusion", and "pluriculturality", while the lowest relationship is between environmental education and neuroeducation. In other words, we should reflect that not only should we introduce new and very current 
subjects in the undergraduate or graduate programs, but we should also study the relationships that these "new" subjects present to see how they support each other, or on the contrary, they have no affinity. In this way, studying technologies will facilitate a better understanding of educational inclusion and pluriculturality, while no matter how much we teach environmental education or neuroeducation we will not obtain affinity between them.

\section{References}

ALGARRA, E. J. D. Ciudadanía, plurilingüismo y pluriculturalidad en contexto hispano japonés de educación superior. Diseño del instrumento de investigación cyasps ${ }^{\circledR}$ y análisis de las concepciones docents. Tesis. Almería: Universidad de Almería, 2020.

ALMEIDA, J.; ELÍAS, M.; VARGINHA, R.; BARBOSA, I. As tecnologias digitais da informação e comunicação como mediadoras na alfabetização de pessoas com transtorno do espectro do autismo: uma revisão sistemática da literatura. Texto Livre: Linguagem e Tecnologia, v. 13, n. 1, p. 45-64, 2020.

BUENdíA, L.; BERROCAL, E.; OlMEdO, E. M.; PEGALAJAR, M.; RUIZ, M.; TOMÉ, M. Valoración por parte del alumnado de las competencias que se pretenden conseguir con al "Master universitario de profesorado en Educación Secundaria Obligatoria, Bachillerato, Formación Profesional y Enseñanza de Idiomas. Bordón, v. 63, n. 3, p. 57-74, 2011.

CAMPOS, A. L. Neuroeducación: uniendo las neurociencias y la educación en la búsqueda del desarrollo humano. La Educación. Revista Digital, n. 143, p. 1-14, 2010.

CASTAÑEDO, C. Escala para la evaluación de actitudes pro-ambientales (EAPA) en estudiantes universitarios. Revista Complutense de Educación, v. 6, n. 2, p. 253-278, 1995.

DÍAZ DE RADA, V. Tipos de encuestas y diseños de investigación. Pamplona: Universidad Pública de Navarra, 2002.

ECHEITA, G.; AINSCOW, M. Educación inclusiva como derecho. Marco de referencia y pautas de actuación para el desarrollo de una revolución pendiente. Tejuelo, n. 12, p. 2446, 2011.

ERTMER, P. A.; OTTENBREIF, T.; LEFTWICH, A.T. Teacher Tecnology Change; How Knowledge, Confidence, Beliefs and Culture Intersect. Journal of Research on Technology in Education, v. 42, n. 3, p. 255-284, 2010.

ESCUDERO, J.M. La educación inclusiva, una cuestión de derecho. Educatio Siglo XXI, v. 30, n. 2, p. 109-128, 2012.

GARCÍA, L.; FERNÁNDEZ, S. Procedimiento de aplicación del trabajo creativo en grupo de expertos. Energética, v. 29, n. 2, p. 46-50, 2008. 
GARCÍA FERRANDO, M. El análisis de la realidad social: métodos y técnicas de investigación. Madrid: Alianza editorial, 2015.

GEORGE, D.; MALLERY, P. SPSS for Windows step by step: A simple guide and reference. 11.0 update. Boston: Allyn \& Bacon, 2003.

GIL, J.; FERNÁNDEZ, M. Publicaciones, interacciones, verdades y mentiras de adolescentes españoles en Instagram. Texto Livre: Linguagem e Tecnologia, v. 13, n. 1, 2020.

GONZALEZ GIL, F.; MARTIN PASTOR, E.; BAZ, B. O. ¿Están los futuros profesores formados en inclusión?: Validación de un cuestionario de evaluación. Aula Abierta, v. 46, n. 2, p. 33-40, 2017.

GUTIÉRREZ, P. R.; FERNÁNDEZ, G. A. M.; VÍLCHEZ, M. L. Estudio exploratorio sobre el panorama actual de la formación inicial del profesorado de secundaria en España. IJERI: International journal of Educational Research and Innovation, n. 11, p. 169-184, 2019.

HERNÁNDEZ, R. S.; GÓMEZ, R. M.; QUINTANA, J. C. M.; FALCÓN, J. A. A. Abandono escolar y formación docente en Educación Secundaria. Aula abierta, v. 47, n. 3, p. 365372, 2018.

IRAOSSI, G. The Power of Survey Design: A User's Guide for Managing Surveys, Interpreting Results, and Influencing Respondents. Washington, D. C.: The World Bank, 2006.

KAISER, H. F. An index of factorial simplicity. Psychometrika, v. 39, n. 1, p. 31-36, 1974.

KAPLAN, D. Structural equation modeling: Foundations and extensions. Thousand Oaks, CA: Sage Publications, 2000.

KLINE, R. Principles and practices of structural equation modeling ( $2 \mathrm{n}$ ed.). New York: Guilford Press, 2005.

LEHOHLA, M.; HLALELE, D. Inclusive class-rooms: An ecosystemic perspective. Journal of Human Ecology, v. 37, n. 3, p. 189-201, 2012.

LÓPEZ, A. La moderación de la habilidad diagnóstico patológico desde el enfoque histórico cultural para la asignatura Patología Veterinaria. Revista Pedagógica Universitaria, v. 13, n. 5, p. 51-71, 2008.

LUQUE, K. E.; LUCAS, M. A. La Neuroeducación en el proceso de enseñanza aprendizaje. Revista Atlante: Cuadernos de Educación y Desarrollo, 2020. Available in: https://www.eumed.net/rev/atlante/2020/06/neuroeducacion.html. Access in: 09 Oct. 2020.

MALLA, F.; ZABALA, I. La previsión del futuro en la empresa (III): el método Delphi. Estudios Empresariales, n. 39, p. 13-24, 1978. 
MANSO AYUSO, J.; MARTÍN, E. Valoración del Máster de Formación de Profesorado de Secundaria: Estudio de casos en dos universidades. Revista de Educación, n. 364, p. 145-169, 2014.

MENGUAL, S. La importancia percibida por el profesorado y el alumnado sobre la inclusión de la competencia digital en educación Superior. Doctoral thesis, Universidad de Alicante, 2011.

ORDONEZ-DIAZ, M. M.; MONTES-ARIAS, L. M.; GARZON-CORTES, G. Importancia de la educación ambiental en la gestión del riesgo socio-natural en cinco países de América Latina y Caribe. Revista Electrónica Educare, v. 22, n. 1, p. 1-19, 2018.

PEÑALVA, A.; SORIANO, E. Objetivos y contenidos sobre interculturalidad en la formación inicial de educadores y educadoras. Estudios sobre Educación, n. 18, p. 37-57, 2010.

SGORLA, K.; COSTA, J.; ZAVILENSKY, K. Projeto Novos Rumos 4.0: pedagogia crítica, metodologias ativas e desenvolvimento humano no ensino de programação básica. Texto Livre: Linguagem e Tecnologia, Belo Horizonte, v. 13, n. 1, p. 120-136, 2020.

SUÁREZ, J.M.; ALMERICH, G.; GARGALLO, B.; ALIAGA, F. Las competencias del profesorado en TIC: estructura básica. Educación XX1, v. 16, n. 1, p. 39-62, 2013.

TERIGI, F. Initial teacher training in Secondary Education: needs to improve, acknowledgement of its limits. Revista de Educación, n. 350, p. 123-144, 2009.

Recebido em dia 20 de abril de 2020. Aprovado em dia 18 de setembro de 2020. 